\title{
A SINGLE-SOLUTION METHOD FOR THE DETERMINATION OF SOLUBLE PHOSPHATE IN SEA WATER
}

\author{
By J. MURPhY and J. P. RILEY \\ Department of Oceanography, The University, Liverpool
}

Of the reagents so far suggested for the reduction of phosphomolybdic acid to molybdenum blue in the determination of phosphate, only stannous chloride (Atkins, 1923; Harvey, 1948), metol (Burton \& Riley, 1956), and ascorbic acid (Greenfield \& Kalber, 1954), give colours of sufficient intensity to be used in the analysis of sea water.

Burton \& Riley (1956) have recently reviewed the use of stannous chloride as a reducing agent in the molybdenum-blue method for the determination of phosphate in sea water. This reagent suffers from a number of disadvantages; in particular that (i) the time taken for development of maximum colour depends on the salinity of the water and its temperature, (ii) the colour fades quite rapidly, (iii) there is a large salt error, and (iv) different batches of molybdate reagent give different extinctions with the same amount of phosphorus.

These workers have proposed the use of metol ( $p$-methyl-aminophenol sulphate) for the reduction of phosphomolybdic acid in the analysis of sea water. This reagent is free from most of the disadvantages of stannous chloride, but requires the development of colour to be carried out at $100^{\circ} \mathrm{C}$.

The use of ascorbic acid for the reduction of phosphomolybdic acid was first reported by Ammon \& Hinsberg (1936). Their method was modified by Lowry, Roberts, Leiner, Wu \& Farr (1954), who used a greater concentration of ascorbic acid. Essentially the same procedure was employed by Chen, Toribara \& Warner (1956) for the micro-determination of phosphorus in biological fluids. Greenfield \& Kalber (1954) have suggested the use of ascorbic acid for the determination of phosphorus in sea water.

When this reductant was investigated, it was found possible to use a single reagent containing ammonium molybdate, ascorbic acid and sulphuric acid, instead of adding the acid molybdate and reducing agent separately, as in the stannous chloride method. The present paper describes the application of this mixed reagent to the determination of soluble phosphate in sea water.

The relative amounts of sulphuric acid and ammonium molybdate in the reagent exert a very marked effect on the formation of phospho- and silicomolybdic acids, and on the ease of reduction of these heteropoly acids and of 
the molybdate ion itself. In order to establish the most suitable composition for the single-solution reagent, experiments were carried out varying the acid and molybdate concentrations systematically in the presence of a fixed amount of ascorbic acid. Aliquots (IO ml.) of distilled water, phosphate solution ( $5 \mu \mathrm{g} \mathrm{PO}_{4}{ }^{3-}-\mathrm{P} / \mathrm{ml}$.) and silicate solution ( $120 \mu \mathrm{g} \mathrm{SiO}_{3}{ }^{2-}-\mathrm{Si} / \mathrm{ml}$.) were treated with mixed reagents containing varied volumes of $2 \%$ ammonium molybdate and $4 \mathrm{~N}$ sulphuric acid, together with $5 \mathrm{ml}$. of $\mathrm{O} \cdot \mathrm{I} \mathrm{M}$ ascorbic acid; the solutions were diluted to $50 \mathrm{ml}$. After $24 \mathrm{~h}$ their optical densities were measured at $827 \mathrm{~m} \mu$ in a I cm cell. The results, which are given in Table I, show that if low reagent blanks and freedom from interference by silicate are to be realized, the final concentrations of acid and molybdate in the solution should be approximately $0.40 \mathrm{~N}$ and $0.10 \%$ respectively. Variation of the final

TABLE 1. DETERMINATION OF OPTIMUM ACID AND MOLYBDATE CONCENTRATIONS FOR ESTIMATION OF PHOSPHATE USING ASCORBIC ACID

Optical densities measured at $827 \mathrm{~m} \mu$ (I cm cell).

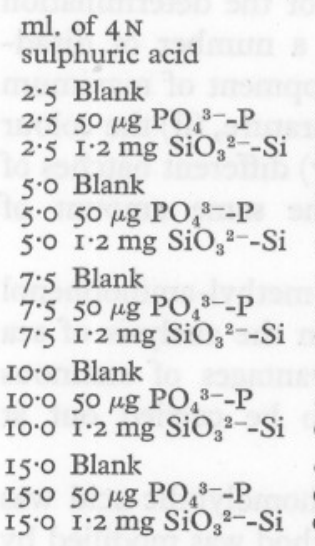

\begin{tabular}{|c|c|c|c|c|c|c|}
\hline I & 2 & 3 & 4 & 5 & 7 & IO \\
\hline O.OIO & - & 0.024 & - & $>2.5$ & - & - \\
\hline 0.445 & - & 0.475 & - & $>2.5$ & - & - \\
\hline 0.074 & - & $>2.5$ & - & $>2.5$ & - & - \\
\hline 0.006 & 0.006 & 0.006 & 0.016 & 0.018 & 0.025 & $>2 \cdot 5$ \\
\hline 0.246 & 0.452 & 0.456 & 0.455 & 0.455 & 0.454 & $>2 \cdot 5$ \\
\hline 0.017 & $0.04 \mathrm{I}$ & 0.043 & 0.204 & 0.609 & I. 59 & $>2.5$ \\
\hline 0.004 & - & 0.009 & - & O.0II & 0.015 & $>2.5$ \\
\hline 0.061 & - & 0.441 & - & 0.442 & 0.477 & $>2.5$ \\
\hline 0.013 & - & 0.024 & - & O.I39 & 0.355 & $>2 \cdot 5$ \\
\hline 0.005 & - & 0.007 & - & 0.012 & 0.008 & 0.005 \\
\hline 0.005 & - & 0.301 & - & 0.450 & 0.438 & 0.440 \\
\hline O.OIO & - & 0.012 & - & 0.017 & 0.018 & 0.022 \\
\hline 0.003 & - & 0.005 & - & O.OII & 0.015 & 0.017 \\
\hline 0.006 & - & 0.038 & - & 0.170 & 0.392 & 0.447 \\
\hline 0.006 & - & O.OII & - & 0.015 & 0.019 & 0.028 \\
\hline
\end{tabular}

ascorbic acid concentration in the range 0.004 to $0.03 \mathrm{M}$ has no effect on the optical density attained. In all subsequent work $8 \mathrm{ml}$. of a reagent $2.5 \mathrm{~N}$ in sulphuric acid, $0.60 \%$ in ammonium molybdate, and $0.03 \mathrm{M}$ in ascorbic acid was used for a final volume of $50 \mathrm{ml}$.

Using this reagent, colour development is complete in both sea water and distilled water after $24 \mathrm{~h}$ at $20^{\circ} \mathrm{C}$, or after $30 \mathrm{~min}$ at $60^{\circ} \mathrm{C}$. The colour once formed is stable for at least $60 \mathrm{~h}$. The calibration curve is independent of changes in batches of reagents.

\section{METHODS}

All measurements of optical density were made with a Unicam S.P. 500 spectrophotometer modified to use $7 \cdot 62$ and $15.24 \mathrm{~cm}$ cells. Distilled water was used in the compensating cell. 


\section{Reagents}

Sulphuric acid $5 \mathrm{~N}$. Dilute $70 \mathrm{ml}$. of concentrated sulphuric acid to $500 \mathrm{ml}$.

Ammonium molybdate $(4 \%)$. Dissolve $20 \mathrm{~g}$ of ammonium molybdate A.R. in distilled water and dilute to $500 \mathrm{ml}$. Store the solution in a Pyrex glass reagent bottle.

Ascorbic acid 0.1 M. Prepare a solution of $1.76 \mathrm{~g}$ of ascorbic acid in $100 \mathrm{ml}$. of distilled water. It is preferable to prepare this solution on the day it is needed, but if this is not possible, the solution may be preserved for about ro days at $0^{\circ} \mathrm{C}$.

Mixed reagent. Mix thoroughly $125 \mathrm{ml}$. of $5 \mathrm{~N}$ sulphuric acid and $37.5 \mathrm{ml}$. of $4 \%$ ammonium molybdate solution. Add $75 \mathrm{ml}$. of ascorbic acid solution and dilute to $250 \mathrm{ml}$. The mixed reagent does not keep well and should be prepared within an hour of using.

\section{Standard solutions}

Stock phosphate solution. Dissolve $0.1757 \mathrm{~g}$ of potassium dihydrogen phosphate in distilled water and dilute to $\mathrm{I} l$. This solution, which contains $40 \mathrm{mg} \mathrm{PO}_{4}{ }^{3}{ }^{3} \mathrm{P} / \mathrm{l}$., should be preserved in a dark glass bottle.

Dilute phosphate solution. Prepare, by dilution of the stock phosphate solution, a solution containing $0.2 \mathrm{mg} \mathrm{PO}_{4}{ }^{3-}-\mathrm{P} / \mathrm{l}$. This standard solution should be prepared daily.

\section{Treatment of apparatus}

Allow apparatus, which is to be used in the determination, to stand overnight filled with concentrated sulphuric acid, and then rinse thoroughly. It is preferable to keep a set of graduated flasks to be used only for the determination of phosphate; after use, they should be washed well and kept filled with distilled water until required again. -If this is done, the treatment with sulphuric acid is only required occasionally.

\section{Determination of phosphate}

Pipette $40 \mathrm{ml}$. of the sea-water sample into a $50 \mathrm{ml}$. graduated flask, add $8 \mathrm{ml}$. of the mixed reagent from a tilt measure and dilute to volume. Allow the colour to develop for $24 \mathrm{~h}$ at room temperature $\left(20^{\circ} \mathrm{C}\right)$. Measure the optical density of the solution at $827 \mathrm{~m} \mu$. Determine the reagent blank in the same manner using freshly distilled water. Calibrate the method using 5, Io and $20 \mathrm{ml}$. aliquots of the dilute standard phosphate (I, 2 and $4 \mu \mathrm{g}$. $\mathrm{PO}_{4}{ }^{3-}-\mathrm{P}$ respectively). To correct the calibration curve for use with sea water multiply the observed optical densities by the appropriate salt error factor (Table 3). The calibration curve remains constant and is independent of changes in the batches of reagents. The colour development may be carried out more rapidly at $60^{\circ} \mathrm{C}$ if desired. Transfer the solution to a loosely stoppered Pyrex flask (treated as described above) and heat it in a water bath at $60^{\circ} \mathrm{C}$ for $30 \mathrm{~min}$. After cooling, measure the optical density of the solution at $827 \mathrm{~m} \mu$.

\section{Beer's law and reproducibility}

Calibration runs were carried out using $\mathrm{I}-25 \mu \mathrm{g} \mathrm{PO}_{4}{ }^{3-}-\mathrm{P}$ in $40 \mathrm{ml}$. of distilled water. The colour was developed for $24 \mathrm{~h}$ at room temperature and the optical densities were then measured at $827 \mathrm{~m} \mu$ in cells of appropriate length. The results, which are given in Table 2 , show a satisfactory repro- 
ducibility and show that Beer's law is obeyed up to a concentration of at least 0.5 p.p.m. $\mathrm{PO}_{4}{ }^{3-}-\mathrm{P}$. Similar figures were obtained when the colour was developed at $60^{\circ}$ or $90^{\circ} \mathrm{C}$.

TABLE 2. DETERMINATION OF PHOSPHORUS

$\begin{array}{ccccc}\mathrm{PO}_{4}{ }^{3-}-\mathrm{P} \mu \mathrm{g} & \begin{array}{c}\text { No. of } \\ \text { determi- } \\ \text { nations }\end{array} & \begin{array}{c}\text { Mean optical } \\ \text { density } \\ (7.62 \mathrm{~cm} \text { cell })\end{array} & \begin{array}{c}\text { Mean } \\ \text { deviation } \\ (\%)\end{array} & \begin{array}{c}\text { Deviation from } \\ \text { linearity } \\ (\%)\end{array} \\ \mathrm{I} & 4 & 0.134 & 0.6 & +0 . \mathrm{I} \\ 2 & 4 & 0.267 & 0.5 & -0.3 \\ 3 & 4 & 0.403 & 0.3 & +0.3 \\ 4 & 4 & 0.534 & 0.5 & -0.3 \\ 5 & 3 & 0.67 \mathrm{I}+ & 0.5 & +0.2 \\ \mathrm{IO} & 3 & 1.342 \dagger & 0.2 & +0.2 \\ \mathrm{I} 5 & 3 & 2.019 \dagger & 0.3 & -0.5 \\ 20 & 3 & 2.667 \dagger & 0.3 & -0.5 \\ 25 & 3 & 3.330 \dagger & 0.3 & \\ & \text { * Less reagent blank. } & & \end{array}$

TABLE 3. SALT ERROR CORRECTIONS

Sea water, $\mathrm{Cl} \%$

Mean optical density for $25 \mu \mathrm{g}$, $\mathrm{PO}_{4}{ }^{3-}-\mathrm{P} \star$

Salt error, \%

Correction factor

$\begin{array}{ccccc}0 & 5 & \text { IO } & \text { I5 } & \text { I9.3 } \\ 0.437 & 0.424 & 0.420 & 0.417 & 0.419 \\ 0 & -2.9 & -3.9 & -4.6 & -4.1 \\ \text { I.00 } & 0.970 & 0.961 & 0.954 & 0.959 \\ \text { I cm cell. } & & & & \end{array}$

SALT ERROR

The effect of the salts of sea water on the intensity of the molybdenum-blue colour, developed by the mixed reagent, has been studied. Filtered sea water, low in phosphate, was diluted with distilled water to give sea waters having chlorinities of 5, IO, I5 and 19.3\%. Duplicate phosphate determinations were made on $40 \mathrm{ml}$. portions of these waters and on $40 \mathrm{ml}$. aliquots which had been enriched with $25 \mu \mathrm{g} \mathrm{PO}_{4}{ }^{3-}-\mathrm{P}$. Colour development was carried out at room temperature. The results, which are summarized in Table 3 , indicate that, as with the metol method, the salt error is not a linear function of chlorinity. For oceanic waters it is small compared with the salt error of the stannous chloride procedure (ca. $20 \%$ ).

\section{INTERFERENCES}

The interference of several ions, known to interfere in molybdenum-blue methods for the determination of phosphorus, has been investigated using the ascorbic acid reagent. Experiments were performed using $40 \mathrm{ml}$. aliquots of distilled water containing these ions, both alone, and in the presence of $5 \mu \mathrm{g}$ of $\mathrm{PO}_{4}{ }^{3-}-\mathrm{P}$. The results (Table 4 ) indicate that of the elements capable of forming molybdenum-blue complexes, only arsenic interferes appreciably. 
In every case the interference is much less than that found with either the stannous chloride or metol methods. The effects of these ions at their normal concentrations in sea water will be quite negligible. High concentrations of copper ( 500 p.p.m.) seriously reduce the intensity of colour formed, presumably by destruction of the ascorbic acid. Even as much as 500 p.p.m. of ferric iron has no effect. Since the colour development is rather prolonged and takes place in $0.24 \mathrm{~N}$ acid, it was thought that hydrolysis of the organic phosphorus compounds present in sea water might occur. This did not prove to be the case, however, since determinations carried out in distilled water, to which fairly readily hydrolysable organic phosphorus compounds had been added, gave no molybdenum-blue colour even after heating for several hours at $70^{\circ} \mathrm{C}$.

TABLE 4. INTERFERENCES OF CERTAIN ELEMENTS

\begin{tabular}{|c|c|c|c|c|c|}
\hline \multirow[b]{2}{*}{ Element } & \multirow[b]{2}{*}{ Added as } & \multirow{2}{*}{$\begin{array}{l}\text { Concen- } \\
\text { tration of } \\
\text { element } \\
\text { (p.p.m.) }\end{array}$} & \multicolumn{3}{|c|}{$\begin{array}{l}\text { Optical density at } 827 \mathrm{~m} \mu \\
\qquad(7.62 \mathrm{~cm} \text { cell })\end{array}$} \\
\hline & & & $\begin{array}{l}\text { No added } \\
\text { phosphate }\end{array}$ & $5 \mu \mathrm{g} \mathrm{PO}_{4}{ }^{3-}-\mathrm{P}$ & Difference \\
\hline- & - & - & 0.055 & 0.710 & 0.655 \\
\hline Copper & $\mathrm{CuSO}_{4}$ & 500 & 0.057 & 0.600 & 0.543 \\
\hline Iron & $\mathrm{FeCl}_{3}$ & 50 & 0.056 & 0.715 & 0.659 \\
\hline Arsenic & Arsenate & I & 0.107 & $0.8 \mathrm{I} 4$ & 0.707 \\
\hline Arsenic & Arsenite & $0 \cdot I$ & 0.059 & 0.715 & 0.656 \\
\hline Silicon & Silicate & 10.0 & 0.057 & 0.710 & 0.653 \\
\hline Vanadium & Vanadate & 500 & 0.085 & 0.743 & 0.658 \\
\hline Germanium & Germanate & $I \cdot O$ & 0.057 & 0.715 & 0.658 \\
\hline
\end{tabular}

\section{SUMMARY}

It has been found that a reagent containing sulphuric acid, ammonium molybdate and ascorbic acid may be used as a single-solution reagent for the determination of phosphate in sea water. Development of the molybdenum-blue colour is complete in $24 \mathrm{~h}$ at room temperature and in $30 \mathrm{~min}$ at $60^{\circ} \mathrm{C}$; the colour is stable for at least 3 days. Beer's law is obeyed closely up to at least $500 \mu \mathrm{g} \mathrm{PO}_{4}{ }^{3-}-\mathrm{P} / 1$. The salt error is approximately $4 \%$ with sea water of chlorinity $19.3 \%$. The interference due to either arsenate or silicate at their concentrations in sea water is negligible.

\section{REFERENCES}

Ammon, R. \& HinsBerg, K., 1936. Colorimetrische Phosphor- und Arsenbestimmung mit Ascorbinsäure. Hoppe-Seyl. Z., Bd. 239, pp. 207-216.

AtKIns, W. R. G., I923. The phosphate content of fresh and salt waters in its relationship to the growth of the algal plankton. F. mar. biol. Ass., U.K., Vol. 13, pp. II9-59.

Burton, J. D. \& Riley, J. P., I956. Determination of soluble phosphate and total phosphorus in sea-water and of total phosphorus in marine muds. Microchim. Acta, 1956, p. 1350. 
Chen, P. S., TORIBARA, T. Y. \& WARnER, H., 1956. Microdetermination of phosphorus. Anal. Chem., Vol. 28, pp. I756-8.

GREENFIELD, L. J. \& KALBER, F. A., I954. Inorganic phosphate measurement in seawater. Bull. mar. Sci. Gulf Carib., Vol. 4, p. 323.

HaRveY, H. W., I948. The estimation of phosphate and total phosphorus in seawaters. F. mar. biol. Ass. U.K., Vol. 27, pp. 337-59.

Lowry, O. H., Roberts, N. R., LeINer, K. Y., WU, M. L. \& FARR, A. L., I954. Quantitative histochemistry of brain. I. Chemical Methods. F. biol. Chem., Vol. 207, pp. I-I6. 